\title{
Electrophoretic Analysis of Protein Patterns in Date Palm "Khalas" Cultivar Leaflets Among Different Locations of Al-Ahsa
}

\author{
Al-Issa Adil Mohammad \\ Department of Biology, College of Education, University of Dammam, Saudi Arabia
}

Received 2013-04-08, Revised 2013-06-06; Accepted 2013-11-07

\begin{abstract}
Proteins extracted from different date palm (Phoenix dactylifera L.) trees "Khalas" Cultivar leaflets, which were collected from 10 different locations of Al-Ahsa oasis in the eastern province of Saudi Arabia, have been analyzed by SDS-PAGE electrophoresis. The present study showed different protein patterns, which revealed by NJ and UPGMA clustering methods into three major clusters 1,2 and 3. Cluster 1 occupies distinct place in the dendrogram that composed of OY, OM, T and SH locations samples were reflected (monomorphism). Cluster 2 included A and AM locations samples that distinguished each by unique band. While the Cluster 3 included B, G, J and M locations samples which separated singly one by one, since there are no enough sharing bands to cluster them together except they were low in their protein content. The results collectively indicated that the difference in clustering patterns is mainly due to genetic variations. Additionally, cluster 1 location samples may represent the proposed original "Khalas" cultivar, while the other tree samples originated from seeds resembled the original cultivar. More genetic and biochemical studies should be conducted to support this conclusion. However, identification of the original "Khalas" cultivar is important to guaranty the superior characteristics of cultivated cultivar trees.
\end{abstract}

Keywords: Phoenix Dactylifera L., Clustering, Phylogenetic, UPGMA, Proteins Patterns, Genetic Variations

\section{INTRODUCTION}

Date palm (Phoenix dactylifera $\mathrm{L} ., 2 \mathrm{n}=2 \times=36$ ) is a monocotyledonous and dioeciously species belonging to Arecaceae family (ITIS, 2010; Elmeer et al., 2011). It widely cultivated in arid regions of the Middle East and North Africa, (Hamza et al., 2011; Al-Yahyai and AlKhanjari, 2008; Khierallah et al., 2011; Elmeer et al., 2011; Jain, 2011; Abul-Soad and Madi, 2010). It is widely distributed in the Eastern Province of Kingdom of Saudi Arabia. There are more than 70 cultivars that have been grown there for ages (Al-Abduolhadi et al., 2011; Al-Issa et al., 2009). Date palm can be propagated by seeds, which usually produce trees bearing inferior fruits. Offshoots are more preferred for conventional propagation because they produce true-to-type trees with fruit quality identical to the mother tree (AlKhalifah et al., 2013; Jain, 2011). The high stability of protein profile makes protein electrophoresis a powerful tool in elucidating the origin and the evolution of cultivated plants (Ladizinsky and Hymowitz, 1979). Therefore, protein pattern analysis by gel electrophoresis has been used in higher plants to study various problems in breeding, genetics, taxonomy, physiology, (Leonardo et al., 2010; Chang et al., 2010; Castillejo et al., 2012; Elshibli and Korpelainen, 2008; Davar et al., 2012) as it has been appreciated as a biochemical tool for studying the phylogentic relationships (Al-Yahyai and Al-Khanjari, 2008).

The phylogenetic analysis based on protein patterns were used to study the genetic relatedness between and among cultivar (El-Hady et al., 2010; Abdulla and Gamal, 2010; Haider et al., 2012). So, it would be helpful in recognizing the originals cultivars. On the other hand, "Khalas" cultivar is one of the most economical date palm cultivars grown in the eastern province of the Saudi Arabia, in Al-Ahsa oasis where known locally that "Khalas" Cultivar 
trees are differed in their fruit quality depending on the location even within the oasis (Al-Mulla, 1997; Asif et al., 1982). Al-Issa (2006) showed in their comparative study to genetic and biochemical differences within "Khalas" cultivar trees growing in two localities. The main aim of the present study is to analyze whether their genetic diversity among "Khalas" cultivar trees according to ten locations of Al-Ahsa oasis using protein profiling. Consequently, "Khalas" cultivar have been selected for electrophoretic proteins analysis by Sodium Dodecyl Sulphate-Polyacrylamide Gel Electrophoresis (SDSPAGE), leaflet tissues collected from 10 different locations within Al-Ahsa oasis which considered as the origin of this cultivar.

\section{MATERIALS AND METHODS}

The samples were collected from juvenile green leaflets from 30 years old and above "Khalas" cultivar trees in each location, the area were samples collected covered the most of Al-Ahsa oasis areas for date palm cultivation, which divided in to three areas: North, Middle and East villages (Table 1 and Fig. 1). The trees were offshoot of previous mother trees which were grown in the same location. The samples transferred immediately to liquid nitrogen, then to deep freezer$20^{\circ} \mathrm{C}$ until the time of usage. The samples were cut into $2 \times 2 \mathrm{~mm}$ before ground in mortar with liquid nitrogen prior to be subjected to protein electrophoretic analysis using the SDS-PAGE.

\subsection{Protein Extraction}

The samples were ground in a mortar by liquid nitrogen, then the proteins extracted by homogenizing $100 \mathrm{mg}$ of ground leaflet samples by half volume stainless steel beads with $1 \mathrm{~mL}$ extracting buffer $(0.5$ $\mathrm{M}$ Tris/HCl buffer, $\mathrm{pH} 6.8+10 \%$ Glycerol v/v $+4 \%$ PVP w/v) at 9/4 min., followed by $10 / 2 \mathrm{~min}$. by using of (Bullet Blender Homogenizer), then incubated overnight at $4^{\circ} \mathrm{C}$. The crude extract was vortexed by using of (VELP vortex mixer), then centrifuged at $12500 \mathrm{rpm}$ for $10 \mathrm{~min}$ by using of (Eppendorf centrifuge 5424), the supernatant was moved to new tubes, while discarded the debris.

\subsection{Protein Concentration}

To the supernatant $1 \mathrm{ml}$ of chilled acetone was added, vortexed, centrifuged at $12500 \mathrm{rpm}$ for $10 \mathrm{~min}$., then acetone discarded, this step repeated twice. After the acetone have been discarded the precipitated protein was incubated at room temperature for $15 \mathrm{~min}$.

\subsection{Resuspending Proteins}

The proteins are redissolving in $150 \mu \mathrm{L}$. of extracting buffer, vortexed, boiled at $95^{\circ} \mathrm{C}$ for $4 \mathrm{~min}$ and then vortexed, centrifuged at $12500 \mathrm{rpm}$ for $10 \mathrm{~min}$, after that loaded in $10 \mu \mathrm{L}$.

\subsection{Electrophoresis}

Discontinuous vertical SDS-Polyacrylamide Gel Electrophoresis (SDS-PAGE) was carried out according to Laemmli (1970) with some modifications, in $12.5 \%$ resolving gels $[6.67 \mathrm{~mL}$ Acrylamide-bis acrylamide $(30 \% \backslash 2.6 \%)+4 \mathrm{~mL}(1.5 \mathrm{M}$ tris/ $\mathrm{HCl}$ buffer $\mathrm{pH} 8.8)+5.05$ $\mathrm{mL} \mathrm{DW}+0.16 \mathrm{~mL}(10 \% \mathrm{SDS})+$ freshly prepared $0.12 \mathrm{~mL}$ $(10 \%$ amm. persulphate $)+0.008 \mathrm{~mL}$ TEMED] and stacking gels $[0.95 \mathrm{~mL}$ Acrylamide-bis acrylamide $(30 \% \backslash 2.6 \%)+1.25 \mathrm{~mL}(0.5 \mathrm{M}$ tris/ $\mathrm{HCl}$ buffer $\mathrm{pH}$ $6.8)+2.72 \mathrm{~mL} \quad \mathrm{DW}+0.05 \mathrm{~mL} \quad(10 \% \mathrm{SDS})+$ freshly prepared $0.025 \mathrm{~mL}(10 \%$ amm. persulphate $)+0.005 \mathrm{ml}$ TEMED]. The run buffer was prepared by dissolving $3.0 \mathrm{gm}$ Tris $+14.1 \mathrm{gm}$ Glycine+1 $\mathrm{gm}$ SDS, in DW to 1 $\mathrm{L}$, while the $\mathrm{pH}$ adjusted to 8.3 and the electrophoresis was carried out by using of (BioRad, Broka $0.75 \mathrm{~mm}$ ) mini electrophoresis system with (BioRad PowerPac Basic) at 100-150 Volts.

\subsection{Staining and Destaining}

The gel was washed with $100 \mathrm{~mL}$ of Gel fixing solution (Ethanol: Acetic Acid: Distilled Water, 5:1:4\% respectively-GFS) for $1 \mathrm{~h}$. with agitation at room temperature, then removed the (GFS). The gel covered with $100 \mathrm{~mL}$ of Gel washing solution (Methanol: Acetic Acid: Distilled Water, 5:1:4\% respectively-GWS) for overnight with agitation at room temperature, then removed the (GWS). The gel covered with $100 \mathrm{~mL}$ of Coomassie brilliant blue R-250 (0.4 g+200 mL (40\% Methanol), after filtered added $200 \mathrm{~mL}$ (20\% acetic acid) for 3-4 $\mathrm{h}$ with agitation at room temperature, removed the stain off the gel, then distained with $100 \mathrm{~mL}$ of (GWS) several times.

\subsection{Band Scoring and Analysis}

Protein bands have been scored, only unambiguous bands coded for presence/absence (I/O). Quantitative evaluation of the protein bands have been done by eye.

\subsection{Protein Profiling}

Molecular weight of electrophoretic protein bands have been calculated according to Weber and Osborn (1969) method using standard protein marker with the following bands starting at the top with 225 K.D. band followed by $150,100,75,50,35,25,15$ and 10 K.D. band, (Table 2). 
Al-Issa Adil Mohammad / American Journal of Agricultural and Biological Sciences 8 (4): 343-349, 2013

Table 1. Areas of the samples, locations with corresponding abbreviations

\begin{tabular}{|c|c|c|c|c|c|c|c|c|c|c|}
\hline \multirow{2}{*}{$\begin{array}{l}\text { Area } \\
----- \\
\text { No. }\end{array}$} & \multirow{2}{*}{\multicolumn{2}{|c|}{$\begin{array}{ll} & \text { North } \\
1 & 2\end{array}$}} & Is whin & . & \multicolumn{3}{|c|}{ Middle } & \multicolumn{3}{|c|}{ East } \\
\hline & & & 3 & 4 & 5 & 6 & 7 & 8 & 9 & \\
\hline Location & $\mathrm{SH}^{\mathrm{a}}$ & $\mathrm{G}^{\mathrm{b}}$ & $\mathrm{J}^{\mathrm{c}}$ & $\mathrm{M}^{\mathrm{d}}$ & $\mathrm{OY}^{\mathrm{e}}$ & $\mathrm{AM}^{\mathrm{f}}$ & $\mathrm{B}^{\mathrm{g}}$ & $\mathrm{A}^{\mathrm{h}}$ & $\mathrm{OM}^{\mathrm{i}}$ & $\mathrm{T}^{\mathrm{j}}$ \\
\hline
\end{tabular}

a. Al-Shoa bah, b. Al-Gurain, c. Julaijalah, d. Al-Mutairfi, e. Al-Oyuni, f. Ain Merjan, g. Al-Battalia, h. Al-Aqar, i. Al-Omran, j. Al-Taraf

Table 2. The marker and the samples electrophoretic protein band

\begin{tabular}{|c|c|c|c|c|c|c|c|c|c|c|}
\hline Marker & $\mathrm{OY}^{\mathrm{e}}$ & $\mathrm{OM}^{\mathrm{i}}$ & $\mathrm{T}^{\mathrm{j}}$ & $\mathrm{M}^{\mathrm{d}}$ & $\mathrm{SH}^{\mathrm{a}}$ & $\mathrm{B}^{\mathrm{g}}$ & $\mathrm{J}^{\mathrm{c}}$ & $\mathrm{AM}^{\mathrm{f}}$ & $\mathrm{G}^{\mathrm{b}}$ & $A^{h}$ \\
\hline
\end{tabular}

$\begin{array}{llllllllll}20 & 20 & 20 & 20 & 20 & 20 & 20 & 20 & 20 & 20 \\ 17 & 17 & 17 & 17 & 17 & 17 & 17 & 17 & 17 & 17\end{array}$

$\begin{array}{rrrrrrrrrr}15 & 14 & 14 & 14 & & 14 & 14 & & 14 & 14 \\ 10 & 12 & 12 & 12 & 12 & 12 & 12 & 12 & 12 & 12\end{array}$

\begin{tabular}{cccccccc}
9 & 9 & 9 & 9 & 9 & 9 & 9 & 9 \\
\hline a. Al-Shoa bah, b. Al-Gurain, c. Julaijalah, d. Al-Mutairfi, e. Al-Oyuni, f. Ain Merjan, g. Al-Battalia, h. Al-Aqar, i. Al-Omran, j. Al-Taraf
\end{tabular}

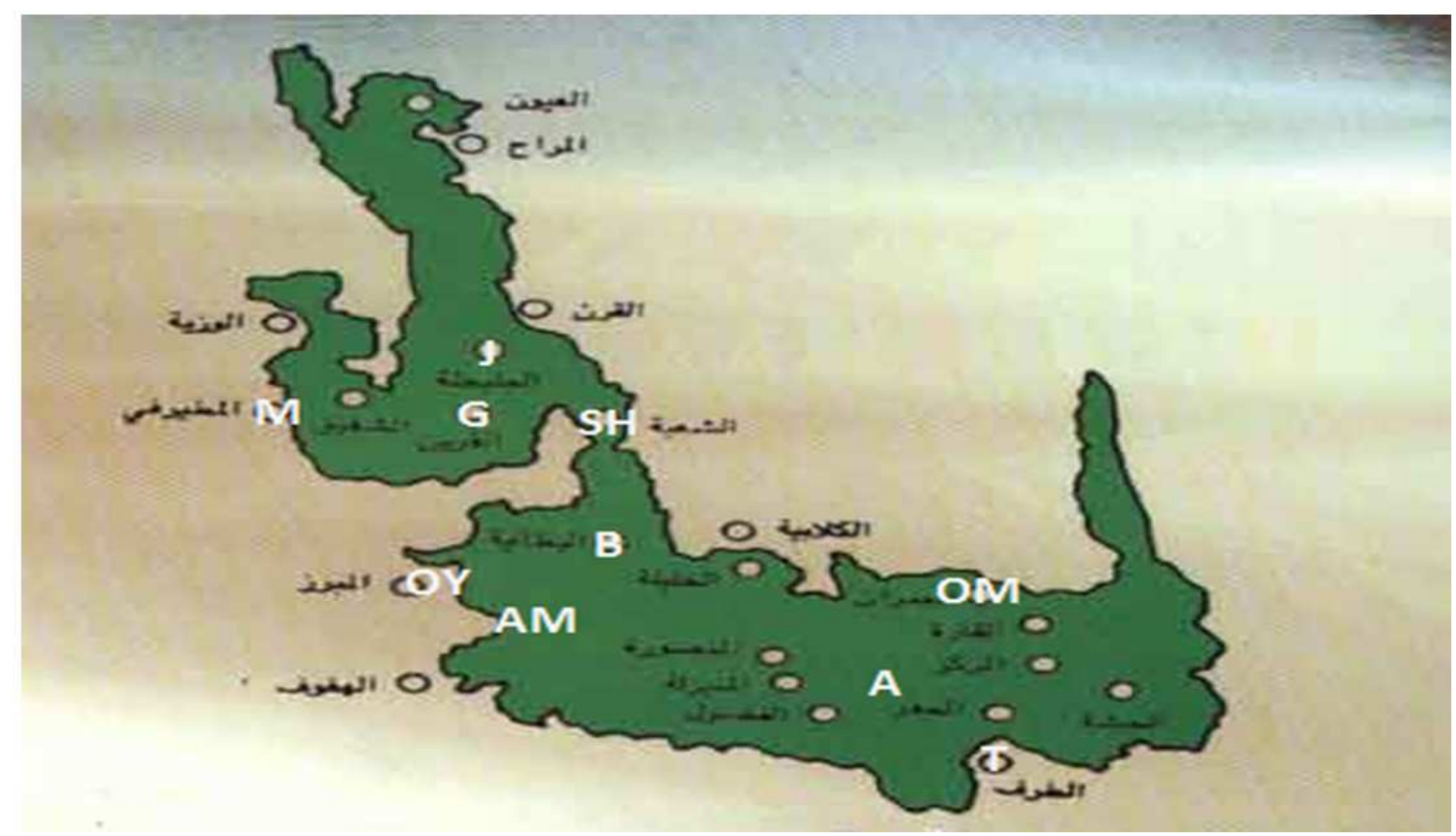

Fig. 1. Map of Al-Ahsa oasis were cultivar samples locations mentioned by abbreviations, SH. Al-Shoa'bah, G. Al-Gurain, J. Julaijalah, M. Al-Mutairfi, OY. Al-Oyuni, AM. Ain Merjan, B. Al-Battalia, A. Al-Aqar, OM. Al-Omran,T. Al-Taraf 


\subsection{Data Analysis}

The results obtained from protein patterns were analyzed statistically, while molecular weight of each protein band was determined (Table 2), Protein bands were scored depending on their presence (I) or absence $(\mathrm{O})$. Jaccard's distances was determined and hierarchical clustering was constructed by NeighborJoining Method (NJ) and Unweighted Pair Group Method With Arithmetic Average (UPGMA).

\section{RESULTS}

In the present study, the total protein extracts of different date palm trees "Khalas" cultivar leaflets samples collected from ten locations were subjected to SDS-PAGE analysis. The proteins were found to be composed of a total of nine bands (Fig. 2, Table 2), The Genetic Distances based on Jaccard's distances method on the basis of presence and absence of bands (Table 3), ranged between 0.0-0.50 (Table 4). Most bands number (8) occurred in A and Am locations, while the least number (4) occurred in M location.

The minimum variation value of 0.0 was observed in between $\mathrm{OY}, \mathrm{OM}, \mathrm{T}$ and $\mathrm{SH}$ locations samples, while the maximum variation values of 0.5 was observed between A, AM and M, locations samples. Protein banding pattern of A and AM locations samples at 98 $\mathrm{kda}$ and $168 \mathrm{kda}$ showing allelic variations, although resolved with low protein content. There are some bands in common between all species (molecular weights: 20, 17, 12, $9 \mathrm{KDa})$. The phylogenetic analysis based on protein pattern according to UPGMA and NJ based dendrograms (Fig. 3 and 4) showed that the different protein patterns were placed into three main clusters. The first cluster is $\mathrm{OY}, \mathrm{OM}, \mathrm{T}$ and $\mathrm{SH}$ samples which represent (monomorphism) and distinguished by 52, 43, 20, 17, 14, 12 and $9 \mathrm{kda}$ bands. The second cluster including $\mathrm{A}$ and AM locations samples which distinguished each by unique band, A sample with 168 kda band, AM sample with 98 kda band (Fig. 3), which is more close to cluster 1 (Fig. 3 and 4). The Third cluster B, G, J and $M$ samples were distinguished by the absence of the two unique band 98 and 168 as the absence of the following bands 52, 43 and $14 \mathrm{kda}$ bands from sample M, 52 and $14 \mathrm{kda}$ bands from sample J, 52 kda band from sample B, 14 kda band from sample G.

Table 3. Protein pattern bands represented by $\mathrm{O}=$ absent, $\mathrm{I}=$ present

\begin{tabular}{llllllllllll} 
Mol. wt. & $\mathrm{OY}^{\mathrm{e}}$ & $\mathrm{OM}^{\mathrm{i}}$ & $\mathrm{T}^{\mathrm{j}}$ & $\mathrm{M}^{\mathrm{d}}$ & $\mathrm{SH}^{\mathrm{a}}$ & $\mathrm{B}^{\mathrm{g}}$ & $\mathrm{J}^{\mathrm{c}}$ & $\mathrm{AM}^{\mathrm{f}}$ & $\mathrm{G}^{\mathrm{b}}$ & $\mathrm{A}^{\mathrm{h}}$ \\
\hline 168 & $\mathrm{O}$ & $\mathrm{O}$ & $\mathrm{O}$ & $\mathrm{O}$ & $\mathrm{O}$ & $\mathrm{O}$ & $\mathrm{O}$ & $\mathrm{O}$ & $\mathrm{O}$ & $\mathrm{I}$ \\
98 & $\mathrm{O}$ & $\mathrm{O}$ & $\mathrm{O}$ & $\mathrm{O}$ & $\mathrm{O}$ & $\mathrm{O}$ & $\mathrm{O}$ & $\mathrm{I}$ & $\mathrm{O}$ & $\mathrm{O}$ \\
52 & $\mathrm{I}$ & $\mathrm{I}$ & $\mathrm{I}$ & $\mathrm{O}$ & $\mathrm{I}$ & $\mathrm{O}$ & $\mathrm{O}$ & $\mathrm{I}$ & $\mathrm{I}$ & $\mathrm{I}$ \\
43 & $\mathrm{I}$ & $\mathrm{I}$ & $\mathrm{I}$ & $\mathrm{O}$ & $\mathrm{I}$ & $\mathrm{I}$ & $\mathrm{I}$ & $\mathrm{I}$ & $\mathrm{I}$ & $\mathrm{I}$ \\
20 & $\mathrm{I}$ & $\mathrm{I}$ & $\mathrm{I}$ & $\mathrm{I}$ & $\mathrm{I}$ & $\mathrm{I}$ & $\mathrm{I}$ & $\mathrm{I}$ & $\mathrm{I}$ & $\mathrm{I}$ \\
17 & $\mathrm{I}$ & $\mathrm{I}$ & $\mathrm{I}$ & $\mathrm{I}$ & $\mathrm{I}$ & $\mathrm{I}$ & $\mathrm{I}$ & $\mathrm{I}$ & $\mathrm{I}$ & $\mathrm{I}$ \\
14 & $\mathrm{I}$ & $\mathrm{I}$ & $\mathrm{I}$ & $\mathrm{O}$ & $\mathrm{I}$ & $\mathrm{I}$ & $\mathrm{O}$ & $\mathrm{I}$ & $\mathrm{O}$ & $\mathrm{I}$ \\
12 & $\mathrm{I}$ & $\mathrm{I}$ & $\mathrm{I}$ & $\mathrm{I}$ & $\mathrm{I}$ & $\mathrm{I}$ & $\mathrm{I}$ & $\mathrm{I}$ & & $\mathrm{I}$ & $\mathrm{I}$ \\
9 & $\mathrm{I}$ & $\mathrm{I}$ & $\mathrm{I}$ & $\mathrm{I}$ & $\mathrm{I}$ & $\mathrm{I}$ & $\mathrm{I}$ & $\mathrm{I}$ & & $\mathrm{I}$ & $\mathrm{I}$ \\
Total & 7 & 7 & 7 & 4 & 7 & 6 & 5 & 8 & 6 & 8 \\
\hline
\end{tabular}

a. Al-Shoa 'bah, b. Al-Gurain, c. Julaijalah, d. Al-Mutairfi, e. Al-Oyuni, f. Ain Merjan, g. Al-Battalia, h. Al-Aqar, i. Al-Omran, j. Al-Taraf.

Table 4. Data matrix of Jaccard`s distance analysis within different samples

\begin{tabular}{|c|c|c|c|c|c|c|c|c|c|c|}
\hline Locations & $\mathrm{OY}^{\mathrm{e}}$ & $\mathrm{OM}^{\mathrm{i}}$ & $\mathrm{T}^{\mathrm{j}}$ & $\mathrm{M}^{\mathrm{d}}$ & $\mathrm{SH}^{\mathrm{a}}$ & $\mathrm{B}^{\mathrm{g}}$ & $\mathrm{J}^{\mathrm{c}}$ & $\mathrm{AM}^{\mathrm{f}}$ & $\mathrm{G}^{\mathrm{b}}$ & $\mathrm{A}^{\mathrm{h}}$ \\
\hline $\mathrm{OY}$ & 0.000 & & & & & & & & & \\
\hline $\mathrm{OM}$ & 0.000 & 0.000 & & & & & & & & \\
\hline $\mathrm{T}$ & 0.000 & 0.000 & 0.000 & & & & & & & \\
\hline M & 0.429 & 0.429 & 0.429 & 0.000 & & & & & & \\
\hline $\mathrm{SH}$ & 0.000 & 0.000 & 0.000 & 0.429 & 0.000 & & & & & \\
\hline B & 0.143 & 0.143 & 0.143 & 0.333 & 0.143 & 0.000 & & & & \\
\hline $\mathrm{J}$ & 0.286 & 0.286 & 0.286 & 0.200 & 0.286 & 0.167 & 0.000 & & & \\
\hline $\mathrm{AM}$ & 0.125 & 0.125 & 0.125 & 0.500 & 0.125 & 0.250 & 0.375 & 0.000 & & \\
\hline G & 0.143 & 0.143 & 0.143 & 0.333 & 0.143 & 0.286 & 0.167 & 0.250 & 0.000 & \\
\hline A & 0.125 & 0.125 & 0.125 & 0.500 & 0.125 & 0.250 & 0.375 & 0.222 & 0.250 & 0.00 \\
\hline
\end{tabular}

a. Al-Shoa bah, b. Al-Gurain, c. Julaijalah, d. Al-Mutairfi, e. Al-Oyuni, f. Ain Merjan, g. Al-Battalia, h. Al-Aqar, i. Al-Omran, j. Al-Taraf. 
Al-Issa Adil Mohammad / American Journal of Agricultural and Biological Sciences 8 (4): 343-349, 2013

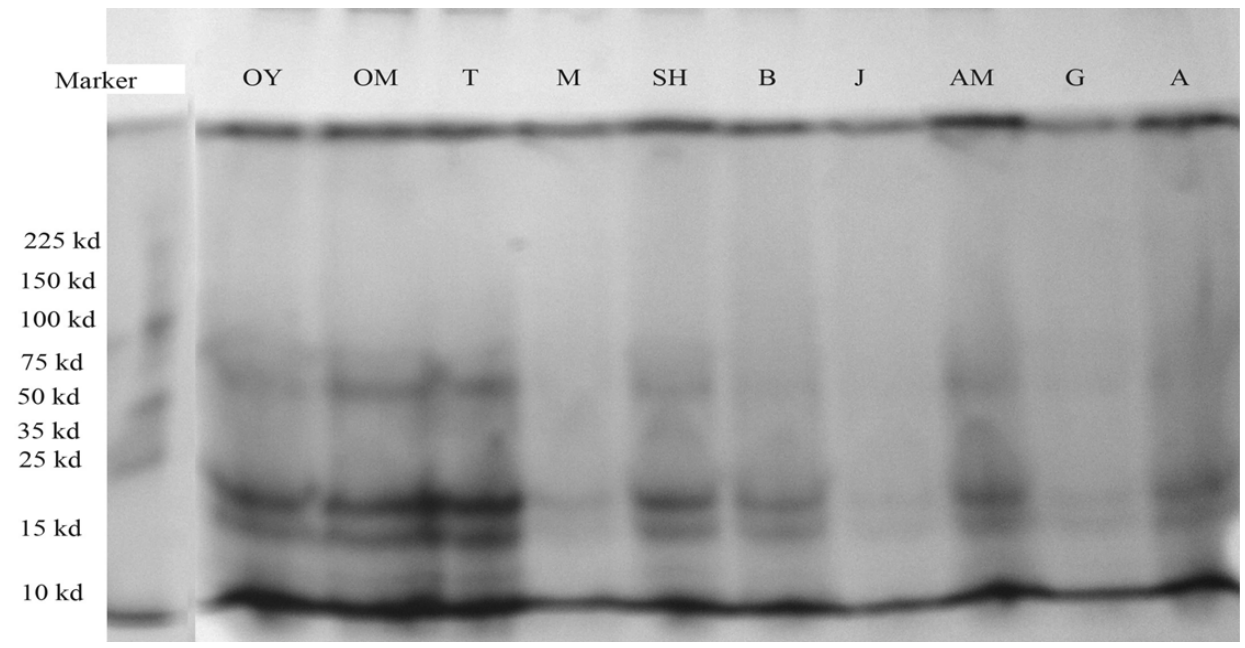

Fig. 2. Electrophoretic proteins patterns of cultivar samples with protein standard marker

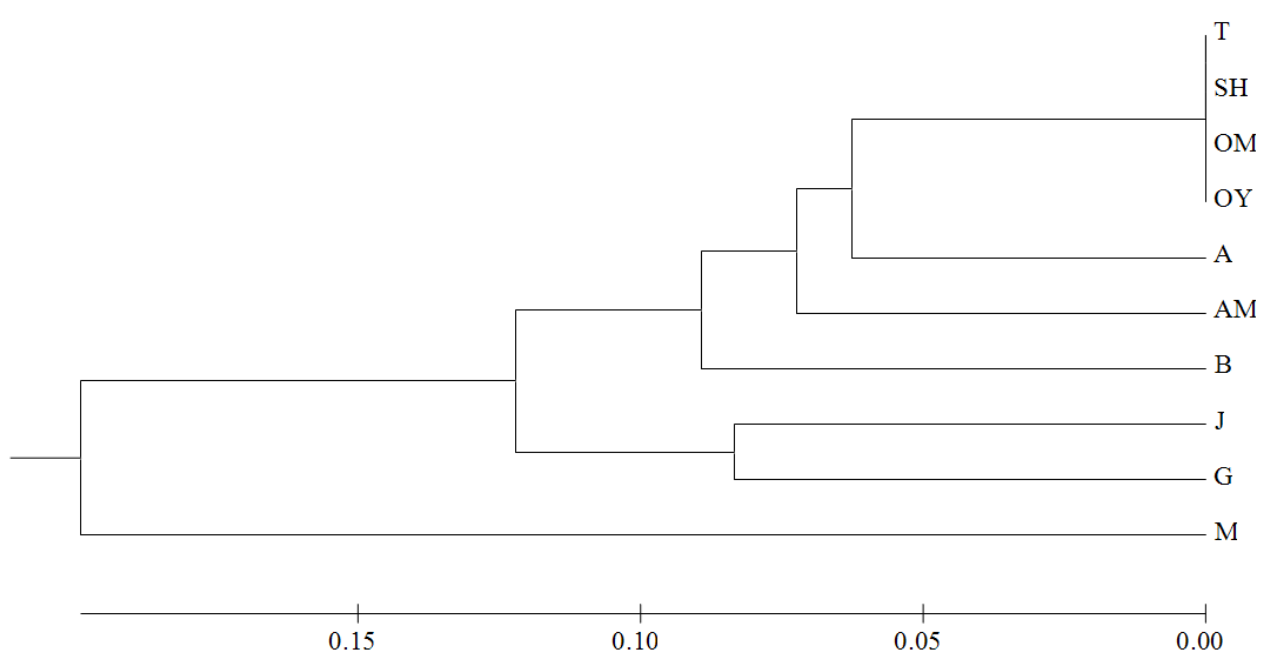

Fig. 3. UPGMA based dendrogram showing genetic relationship among the cultivar samples based on Jaccard's distance

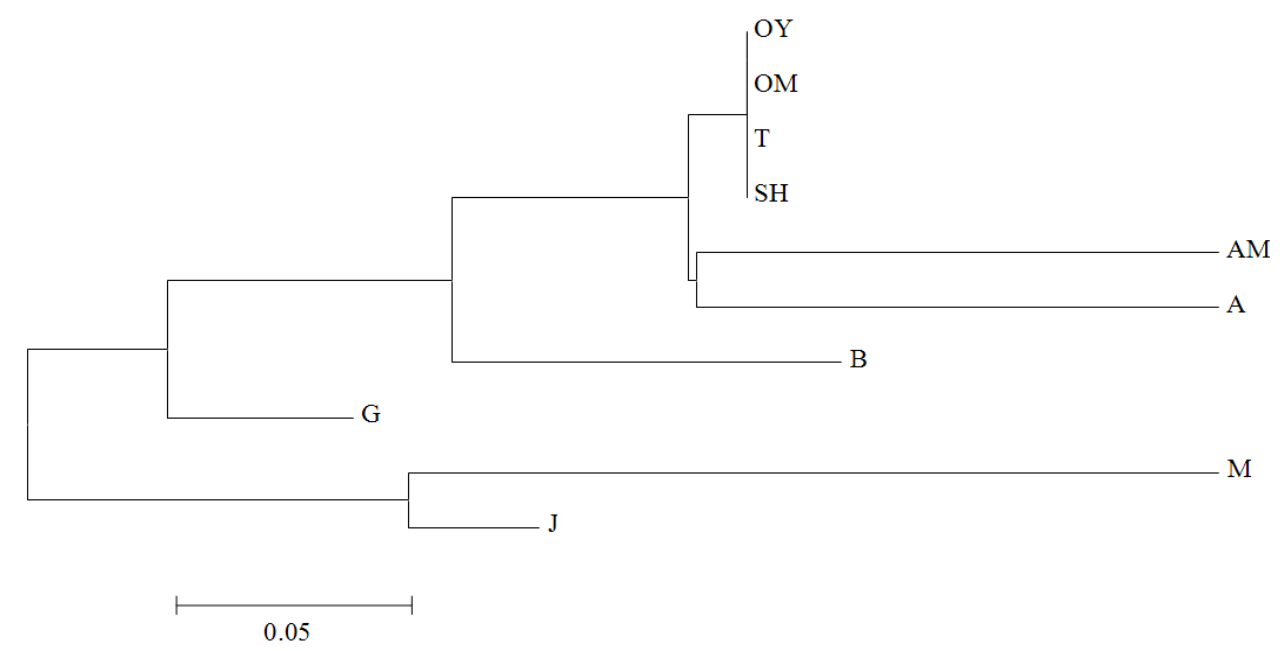

Fig. 4. Neighbor Joining (NJ) based dendrogram showing genetic relationship among the cultivar samples of based on Jaccard's distance 
This cluster samples were separated singly one by one, except $\mathrm{J}$ and $\mathrm{G}$ locations samples were clustered both together under UPGMA dendrogram (Fig. 3), also J and $\mathrm{M}$ both clustered together under $\mathrm{NJ}$ dendrogram (Fig. 4). Almost each sample in cluster 3 has specific banding pattern but there are no enough sharing bands to cluster them together and to show their relatedness except they were low in their protein content.

\section{DISCUSSION}

Since this study have been done to recognize and identify the original "Khalas" cultivar among many "Khalas" cultivar trees growing in Al-Ahsa oasis, the results revealed that the complete similarity in the electrophoretic pattern were in between samples of cluster 1 , since the minimum variation values of 0.0 based on Jaccard's distance (Table 4) was observed in between this cluster, which include OY, OM, T and SH locations samples (Fig. 1 and 2), however all the three areas of Al-Ahsa oasis of this study have been represented in this cluster, $\mathrm{SH}$ belong to North, OY belong to the Middle, $\mathrm{OM}$ and $\mathrm{T}$ belong to East areas (Fig. 1), where it could be used as an indicator to the original "Khalas" cultivar trees. Additionally cluster 2 samples for A and AM locations are the closest to cluster 1 , since variation values of 0.125 based on Jaccard's distance was observed between both cluster 1 and 2 samples (Table 4), were each sample of cluster 2 differed with one band from samples of cluster 1, as another indicator that the cluster 1 sample trees may represent the original Khalas cultivar. It have been conducted by this study results that there is differences in protein patterns within "Khalas" cultivar trees. The genetic differences observed in this study agree with the previous study of Al-Issa (2006) and support the probability of some cultivars trees grown from seeds resembled the original one, then distributed later as an original cultivar (Devanand and Chao, 2003).

\section{CONCLUSION}

It could be concluded from this study that there is a genetic differences among "Khalas" cultivar date palms and the Identification of the original "Khalas" cultivar is important to guaranty the superior characteristics of cultivated trees. Undoubtedly it needs to be subject to more studies. Furthermore, DNA markers should be used to show the genetic structures and variations within "Khalas" cultivar trees, to confirm the fingerprint of the original "Khalas" cultivar. In the long term, the goals should be included the recognizing of the other original cultivars of date palm trees which represent nutritional values and economical importance.

\section{ACKNOWLEDGEMENT}

The research would like to thank University of Dammam, The Scientific Research Deanship for research supporting and to thank Eng. Khalid Khalil AlJeri, at "Al-Hassa Irrigation and Drainage Authority" for his efforts in collecting samples have been studied, Aassistance of Mr. J. El-Tayeb is much appreciated.

\section{REFERENCES}

Abdulla, M. and O. Gamal, 2010. Investigation on molecular phylogeny of some date palm (Phoenix dactylifera L.) cultivars by protein, RAPD and ISSR markers in Saudi Arabia. AJCS, 4: 23-28.

Abul-Soad, A.A. and S.M. Mahdi, 2010. Commercial production of tissue Culture date palm (Phoenix dactylifera L.) by inflorescence technique. JGEB, 8: 39-44.

Al-Abduolhadi, I.A., S. Al-Ali, K. Khurshid, F. AlShryda and A.M. Al-Jabr et al., 2011. Assessing fruit characteristics to standardize quality norms in date cultivars of Saudi Arabia. Ind. J. Sci. Technol., 4: 1262-1266.

Al-Issa, A.M., 2006. Echophysiological comparison between three cultivars of date palm in Al-Ahsa and Al-Qatif in Saudi Arabia. PhD. Thesis, King Saud University-Riyadh-Saudi Arabia.

Al-Issa, A.M., A.A. Al-Helal and F.A. Al-Saad, 2009. The effect of site and cultivar on the protein patterns in three cultivars of date palm leaflets and roots grown in Al-Ahsa and Al-Qatif in Saudi Arabia using electrophoretic analysis technique. Sci. J. KFU., 10: 1-22.

Al-Khalifah, N.S., E. Askari and A.E. Shanavaskhan, 2013. Date palm tissue culture and genetical identification of cultivars grown in Saudi Arabia. National Center for Agriculture Technologies, KACST, Saudi Arabia.

Al-Mulla, A.O., 1997. Under Date Palm Shades. 1st Edn., New National House for Pub., Khobar, Saudi Arabia.

Al-Yahyai, R. and S. Al-Khanjari, 2008. Biodiversity of date palm in the Sultanate of Oman. Afr. J. Agric. Res., 3: 389-395.

Asif, M.I., O. Al-Tahir and M.S. Al-Kahtani, 1982. Inter-Regional and inter-cultivar variations in dates grown in the Kingdom of Saudi Arabia. Proceedings of the 1st Symposium on the Date Palm, (SDP' 82), KFU, Al-Hassa, pp: 234-248.

Castillejo, M.A., M.F. Aparicio and D. Rubiales, 2012. Proteomic analysis by two-Dimensional Differential in Gel Electrophoresis (2D DIGE) of the early response of Pisum sativum to Orobanche crenata. J. Exp. Botany, 63: 107-119. DOI: 10.1093/jxb/err246, PMID: 21920908 
Chang, I.F., P.J. Chen, C.H. Shen, T.J. Hsieh and Y.W. Hsu et al., 2010. Proteomic profiling of proteins associated with the rejuvenation of Sequoia sempervirens (D. Don) Endl. Proteome Sci., 8: 6464. PMID: 21143964

Davar, R., R. Darvishzadeh and A. Majid, 2012. Sclerotinia-induced accumulation of protein in the basal stem of resistant and susceptible lines of sunflower. Not. Bot. Horti. Agrobo., 40: 119-124.

Devanand, P.S. and C.T. Chao, 2003. Genetic variation within 'Medjool' and 'Deglet Noor' date (Phoenix dactylifera L.) cultivars in California detected by fluorescent-AFLP markers. J. Hort. Sci. Biotechnol., 78: 405-409.

El-Hady, E.A.A.A., A.A.A. Haiba, N.R. Abd, A.A. Rizkalla and Elham et al., 2010. Phylogenetic Diversity and Relationships of Some Tomato Varieties by Electrophoretic Protein and RAPD analysis. J. Am. Sci., 6: 434-441.

Elmeer, K., H. Sarwath, J. Malek, M. Baum and A. Hamwieh, 2011. New microsatellite markers for assessment of genetic diversity in date palm (Phoenix dactylifera L.). 3 Biotech, 1: 91-97. DOI: 10.1007/s13205-011-0010-z

Elshibli, S. and H. Korpelainen, 2008. Microsatellite markers reveal high genetic diversity in date palm (Phoenix dactylifera L.) germplasm from Sudan. Genetica, 134: 251-260. DOI: 10.1007/s10709-0079232-8

Haider, N., I. Nabulsi and M.N. Ali, 2012. Phylogenetic Relationships among date palm (Phoenix dactylifera L.) cultivars in Syria using RAPD and ISSR markers. J. Plant Biol. Res., 1: 12-24.
Hamza, H., M. Elbekkay, M.A. Ben Abderrahim and A.A. Ferchichi, 2011. Molecular and morphological analyses of date palm (Phoenix dactylifera L.) subpopulations in southern Tunisia. Spanish J. Agric. Res., 9: 484-493. DOI: 10.5424/sjar/20110902-271-10

ITIS, 2010. Phoenix dactylifera L. Taxonomical Serial No. 42458. ITIS Report.

Jain, M.S., 2011. Prospects of in vitro conservation of date palm genetic diversity for sustainable production. Emir. J. Food Agric., 23: 110-119.

Khierallah, H., S. Bader, M. Baum and A. Hamwieh, 2011. Assessment of genetic diversity for some Iraqi date palms (phoenix dactylifera L.) using Amplified Fragment Length Polymorphism (AFLP) markers. Afr. J. Biotechnol., 10: 9570-9576. DOI: 10.5897/AJB11.055

Ladizinsky, G. and T. Hymowitz, 1979. Seed protein electrophoresis in taxonomic and evolutionary studies. Theor. Appl. Genet., 54: 145-151. DOI: 10.1007/BF00263044

Laemmli, U.K., 1970. Cleavage of structural proteins during the assembly of the head of bacteriophage T4. Nature, 227: 680-685. PMID: 5432063

Leonardo, L.C.D., T.S. Balbuena, S. Vanildo, C.S. Catarina and A. Schevchenko et al., 2010. Twodimensional gel electrophoretic protein profile analysis during seed development of Ocotea catharinensis: A recalcitrant seed species. Braz. J. Plant Physiol., 22: 23-33. DOI: 10.1590/S167704202010000100003

Weber, K. and M. Osborn, 1969. The reliability of molecular weight determinations by dodecyl sulfatepolyacrylamide gel electrophoresis. J. Biol. Chem., 244: 4406-4412. 